Trinity University

Digital Commons @ Trinity

Biology Faculty Research

Biology Department

2018

\title{
The Evolution of Androgen Receptor Expression and Behavior in Anolis Lizard Forelimb Muscles
}

Michele A. Johnson

Trinity University, mjohnso9@trinity.edu

Bonnie K. Kircher

kircherbk@gmail.com

Diego J. Castro

Trinity University

Follow this and additional works at: https://digitalcommons.trinity.edu/bio_faculty

Part of the Biology Commons

\section{Repository Citation}

Johnson, M.A., Kircher, B.K., \& Castro, D.J. (2018). The evolution of androgen receptor expression and behavior in Anolis lizard forelimb muscles. Journal of Comparative Physiology A: Neuroethology, Sensory, Neural, and Behavioral Physiology, 204(1), 71-79. doi:10.1007/s00359-017-1228-y

This Article is brought to you for free and open access by the Biology Department at Digital Commons @ Trinity. It has been accepted for inclusion in Biology Faculty Research by an authorized administrator of Digital Commons @ Trinity. For more information, please contact jcostanz@trinity.edu. 


\title{
The evolution of androgen receptor expression and behavior in Anolis lizard forelimb muscles
}

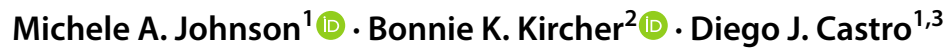

Received: 1 June 2017 / Revised: 12 October 2017 / Accepted: 9 November 2017 / Published online: 15 November 2017

c) Springer-Verlag GmbH Germany, part of Springer Nature 2017

\begin{abstract}
The motor systems that produce behavioral movements are among the primary targets for the action of steroid hormones, including androgens. Androgens such as testosterone bind to androgen receptors (AR) to induce physiological changes in the size, strength, and energetic capacity of skeletal muscles, which can directly influence the performance of behaviors in which those muscles are used. Because tissues differentially express AR, resulting in tissue-specific sensitivity to androgens, AR expression may be a major target of selection for the evolution of behavior. Anolis lizards (i.e., anoles) provide a robust system for the study of androgen-regulated traits, including the behavioral traits that facilitate social display and locomotion. In this study, we examined six anole species that demonstrate significant variation in the behavioral use of the forelimbs to measure the proportion of myonuclei in the bicep muscles that express AR. Using phylogenetic comparative analyses, we found that species with a greater proportion of nuclei positive for AR expression in the biceps exhibited greater frequencies of locomotor movements and pushup displays. These results suggest that AR expression in skeletal muscles may influence the evolution of androgen-regulated behaviors in this group.
\end{abstract}

Keywords Androgen receptor · Anolis lizards $\cdot$ Bicep $\cdot$ Pushup $\cdot$ Locomotion

\section{Introduction}

An animal's performance of a complex behavior requires the integration and transmission of signals from the central nervous system to the peripheral motor systems, which ultimately produce the behavioral movements. Because even closely related species may vary extensively in movement patterns (e.g., Prum 1990; Hale et al. 2002; Ord and Martins 2006), studies of the physiological differences in musculoskeletal systems may provide critical insights into the evolution of this behavioral variation. While a robust body of work has explored the relationships between motor systems and behavior within individual model species, phylogenetic comparative studies that explicitly examine the evolution of

Michele A. Johnson

mjohnso9@trinity.edu

1 Department of Biology, Trinity University, San Antonio, TX 78212, USA

2 Department of Biology, University of Florida, Gainesville, FL 32611, USA

3 Present Address: Escuela Internacional Sampedrana, San Pedro Sula, Honduras the endocrine mechanisms of behavior remain somewhat rare (but see e.g., Hale et al. 2002; Johnson and Wade 2010; Fuxjager et al. 2015; Mangiamele et al. 2016).

The action of steroid hormones, including androgens, is one of the primary physiological bases of vertebrate social behavior and performance. Androgens play significant roles in the development, maintenance, and expression of male reproductive morphology and behavior (reviewed in Adkins-Regan 2005), and across vertebrates, the peripheral motor system is a major androgenic target (e.g., Rand and Breedlove 1992; Brantley et al. 1993; Regnier and Herrera 1993; Veney and Wade 2004). In particular, androgens influence the size, strength, and growth rates of skeletal muscles (Herbst and Bhasin 2004), often in sex- or species-specific patterns (e.g., Cox et al. 2009), yet they can also affect cellular processes such as respiration and metabolism within muscle cells. In the only study to date on androgenic effects on the muscular transcriptome, Fuxjager et al. (2016) found that in the forelimb musculature of two passerine bird species (golden-collared manakins, Manacus vitellinus, and zebra finches, Taenopygia guttata), testosterone differentially regulated gene expression in species- and muscle-specific patterns. Most notably, androgens influenced expression 
in genes and gene networks associated with the contractile force and energetic capacity of the muscle fibers, traits with wide-ranging potential effects on an animal's behavioral use of a muscle.

The presence of these tissue-specific androgenic effects suggests that a given level of circulating plasma androgens can differentially affect tissues within the same organism. The most likely mechanism for such an effect is the differential expression of androgen receptors (AR), as tissues with greater AR expression are likely more sensitive to the action of androgens than tissues with lower AR. This offers a clear target of selection for the evolution of behavior: variation in the use of skeletal muscles across species may be controlled by variation in AR expression in those muscles. In comparative studies of manakins (Fuxjager et al. 2015) and frogs (Mangiamele et al. 2016), this hypothesis received strong support: species in which limb musculature is used to perform elaborate behavioral movements exhibit greater AR expression in those muscles than species that do not perform these movements, and they exhibit greater AR expression in muscles used to perform these movements than in muscles not associated with the behaviors. Yet, these studies focus on complex behaviors that are unique to the taxa of study: wing-snap sonations in golden-collared manakins and footflagging displays in Borean rock frogs (Staurois parvus). However, differential AR expression may also drive the evolution of muscle use in highly frequent behaviors such as locomotion, or simple social displays such as lizard pushups.

Lizards in the genus Anolis (i.e., anoles) provide an excellent system for studies of the evolution of the physiological mechanisms underlying behavior. Anoles are extraordinarily diverse, with approximately 400 species that occur throughout the Caribbean, Central and South America, and the southeastern US (Losos 2009). There is a long history of field and laboratory studies of this group, providing extensive information on the diversity of their behavior, ecology, and morphology (reviewed in Losos 2009), and a robust phylogeny is available for the genus (Pyron et al. 2013). Further, the neural, muscular, and endocrine mechanisms of social behaviors have been well studied in one anole species, Anolis carolinensis (the Carolina green anole; reviewed in Wade 2012), including quantification of AR in myonuclei (Holmes and Wade 2005; Neal and Wade 2007).

Among the most common behaviors exhibited by anoles are locomotor movements and social displays, behaviors that are easily observed in the field and readily quantified. Anoles primarily use arboreal perches such as tree trunks and branches, bushes, or tall grass, and they move along and among perches using crawls, runs, and jumps (e.g., Irschick and Losos 1998). In the Caribbean, most anole species exhibit specializations to particular microhabitats (e.g., tree trunks, or grasses and bushes), and these microhabitat specialists (called ecomorphs) vary in their rates of locomotion in these habitats (Johnson et al. 2008). Social displays in this group generally consist of species-specific combinations of pushups and head-bobs, performed in conjunction with the extension of a throat fan called a dewlap, and in some species, with display modifiers such as the development of an eyespot or raising a nuchal crest (Jenssen 1977). These displays are performed by both sexes during courtship, territorial defense, and predator pursuit deterrence (Leal and Rodriguez Robles 1997), or in the context of species recognition (Nicholson et al. 2007), with males displaying far more frequently than females (e.g., Jenssen et al. 2000). Although levels of circulating androgens vary among anole species, these differences are not associated with variation in aggressive display behaviors (Husak and Lovern 2014). This suggests that instead, AR expression in the skeletal muscles that control display behaviors may mediate the interaction between androgens and behavior in this group.

Both pushup displays and locomotor behaviors require the contraction of a suite of forelimb skeletal muscles. First, biceps have been hypothesized (Herrel et al. 2008; Anzai et al. 2014) and demonstrated (Foster and Higham 2014) to be important in elbow flexion (decrease in the angle between the forearm and the hind limb) during locomotion, a movement also involved in the pushup display. In humans, the biceps are a major contributor during pushup behavior, and variation in bicep activation is correlated with pushup speed, such that slower pushups result from greater bicep activation (Chou et al. 2011). Other major contributors to the pushup movement in humans are the supinator, pronator teres, triceps brachii, middle deltoid, anterior deltoid, pectoralis major and posterior deltoid (Chou et al. 2011). All of these muscles are present in lizards (Haines 1939; Suzuki et al. 2002) and some have been specifically documented in Anolis lizards (Anzai et al. 2014). In particular, Anzai et al. (2014) report that the anterior deltoid (M. clavodeltoideus) functions as a humeral protractor, the posterior deltoid (M. scapulodeltoideus) functions as a humeral abductor, the pectoralis major (M. pectoralis profundus) functions as a humeral adductor, and the triceps brachii (of the triceps complex) function as an elbow extensor in Anolis. Humeral abduction, adduction, and protraction, and elbow extension are all movements that occur during locomotion and pushup displays.

In this study, we tested the hypothesis that AR expression in anole forelimb muscles, and in the biceps in particular, is positively associated with the behavioral use of the forelimbs. To this end, we selected six Anolis species that represent a wide range of locomotor movement and display rates (Johnson et al. 2008; Johnson and Wade 2010). These six species include $A$. carolinensis from the southeastern US, and five species from southwestern Dominican Republic: $A$. bahorucoensis (the Bahoruco long-snouted anole), A. brevirostris (the shortnose anole), A. coelestinus (the Hispaniolan 
green anole), A. cybotes (the largehead anole), and A. olssoni (the desert grass anole; Fig. 1). In this species group, we predict that species that perform higher rates of locomotor movements and pushups will express more AR in biceps than those that perform these behaviors less frequently.

\section{Materials and methods}

\section{Field behavioral data and tissue collection}

To quantify differences in locomotor and pushup behaviors, we conducted standardized behavioral observations on adult male lizards of each of six Anolis species (Table 1) during five summer breeding seasons across 2006-2015, as follows. Observations occurred between 0700 and 1800, and never during inclement weather (i.e., rain), as lizards may take refuge during those times (Hertz et al. 1993). Individuals were located for observations by walking slowly through the field sites, and undisturbed lizards were observed for 10-120 min from a minimum distance of $10 \mathrm{~m}$. In 2006, 2010, and 2014 observations, anoles within a study plot were individually marked using bead tags sewn into the tail muscle (Fisher and Muth 1989), and released at their site of capture. After a minimum of 24-h post-capture, we conducted undisturbed focal observations of marked individuals (up to a maximum of $3 \mathrm{~h}$ per individual), and calculated average rates of pushup displays and locomotor movements for each individual (see Johnson et al. 2010; Bush et al. 2016 for details). In 2011 and 2015 observations, we observed unmarked males. As male anoles are generally thought to remain in a small home range or territory (Stamps 1977, 1994; but see Kamath and Losos 2017), we avoided repeated observations in the same immediate area to minimize the probability of performing multiple observations on the same lizards. During observations, we recorded all locomotor behaviors (with each movement defined as a crawl, run, or jump) and pushup displays. We calculated the average rates of locomotor movements and pushup displays for each species for use in statistical analysis. Some data for these and additional behavioral traits collected during these observations were previously reported in Johnson et al. (2008; foraging mode), Johnson et al. (2010; territorial defense), Johnson and Wade (2010; dewlap display), Dill et al. (2013; locomotor behavior in A. carolinensis), Johnson et al. (2014; copulation), and Bush et al. (2016; territorial behavior of A. carolinensis).

Fig. 1 Phylogeny of the six Anolis lizard species included in this study, pruned from the squamate phylogeny of Pyron et al. (2013). Photograph of $A$. bahorucoensis by T. Sanger

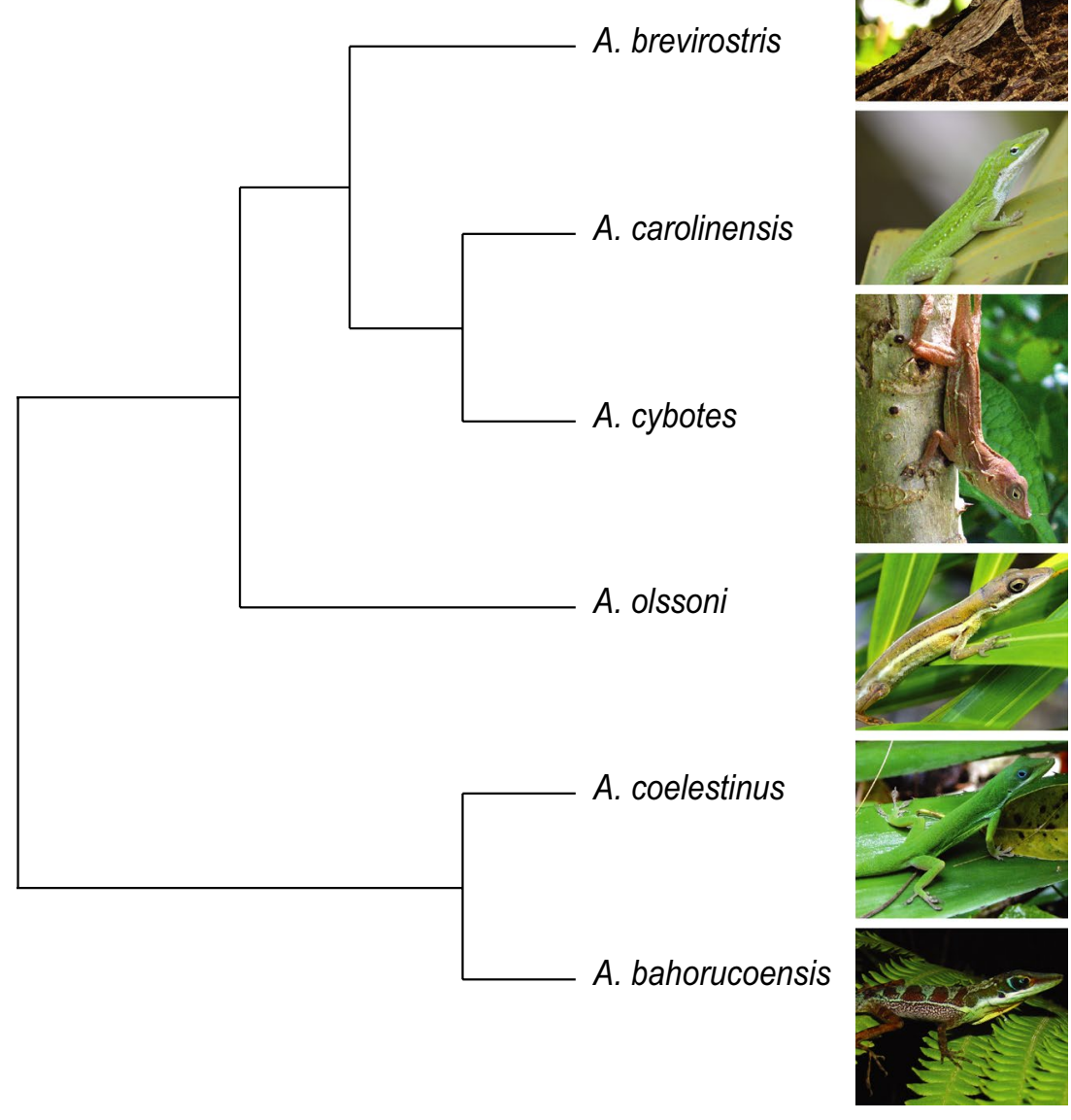


Table 1 Localities of behavioral observations of six Anolis lizard species

\begin{tabular}{|c|c|c|c|c|c|}
\hline Species & $\begin{array}{l}\text { Number } \\
\text { observed }\end{array}$ & Hours observed & Year(s) of observation & Locality & GPS coordinates \\
\hline A. bahorucoensis & 10 & 23.2 & 2006 & Polo, Dominican Republic & $18.105,-71.276$ \\
\hline A. brevirostris & 85 & 57.5 & 2011,2015 & $\begin{array}{l}\text { Coralsol Beach Resort, Barahona, Dominican } \\
\text { Republic }\end{array}$ & $18.062,-71.111$ \\
\hline A. carolinensis & 107 & 123.3 & 2010,2014 & Palmetto State Park, Gonzales, Texas, USA & $29.593,-97.585$ \\
\hline A. coelestinus & 87 & 60.0 & $2006,2011,2015$ & $\begin{array}{l}\text { Coralsol Beach Resort, Barahona, Dominican } \\
\text { Republic }\end{array}$ & $18.062,-71.111$ \\
\hline A. cybotes & 113 & 74.1 & $2006,2011,2015$ & $\begin{array}{l}\text { Coralsol Beach Resort, Barahona, Dominican } \\
\text { Republic }\end{array}$ & $18.062,-71.111$ \\
\hline A. olssoni & 31 & 49.6 & 2006,2015 & $\begin{array}{l}\text { Coralsol Beach Resort, Barahona; and Bani, } \\
\text { Dominican Republic }\end{array}$ & $\begin{array}{l}18.062,-71.111 \\
18.232,- \\
70.347\end{array}$ \\
\hline
\end{tabular}

In 2011, we captured A. brevirostris, A. coelestinus, $A$. cybotes, and A. olssoni for measures of bicep muscle tissues by hand at night on July 11, 2011, on the grounds surrounding Coralsol Beach Resort in Barahona, Dominican Republic; and A. bahorucoensis on July 11, 2011 in the montane region near Polo, Dominican Republic. We collected A. carolinensis in mid-July 2011 at Palmetto State Park in Gonzales, Texas. Each of these localities were the same localities in which behavioral observations of the species occurred, but the individuals for which behavioral data were collected were different individuals than those used for tissue analysis. We kept lizards in air-filled plastic bags upon capture and moved them to cloth bags for transport. Upon arrival at Trinity University, at most 2 days after capture, we measured each lizard's snout-vent length (SVL) using Mitutoyo digital calipers (to the nearest $0.5 \mathrm{~mm}$ ), and mass (to the nearest $0.1 \mathrm{~g}$ ) using Pesola spring scales. The lizards were then immediately euthanized via rapid decapitation, and muscles from the forelimb (including the biceps) were flash-frozen on dry ice and stored at $-80^{\circ} \mathrm{C}$ until further processing.

\section{Quantification of AR in muscle tissues}

We sectioned frozen forelimb muscle tissues with a cryostat at $20 \mu \mathrm{m}$ in six series (i.e., multiple sections were collected on a single slide at $120 \mu \mathrm{m}$ intervals) and thaw-mounted the tissues on SuperFrost Plus microscope slides (Fisher Scientific; Hampton, NH, USA). We sectioned the medial portion of each forelimb on a transverse plane, such that cross-sections of the muscle tissues were examined. Sectioned tissues were stored at $-80^{\circ} \mathrm{C}$ until we performed immunocytochemistry.

To measure AR in the bicep tissues, we adapted immunocytochemistry protocols previously used in green anole lizard (A. carolinensis) muscle tissues, as described in Holmes and Wade (2005) and Neal and Wade (2007). All tissues were processed in a single immunocytochemistry run. In brief, slides from a single series were warmed to room temperature, and tissues were fixed in $4 \%$ paraformaldehyde in $0.1 \mathrm{M}$ phosphate buffered saline (PBS) for $10 \mathrm{~min}$. Slides were rinsed three times for $5 \mathrm{~min}$ in $0.1 \mathrm{M}$ PBS between all steps. Following a 30-min incubation in $0.5 \% \mathrm{H}_{2} \mathrm{O}_{2}$ to remove endogenous peroxidases, slides were incubated in $4 \%$ normal donkey serum in $0.1 \mathrm{M}$ PBS with $0.2 \%$ Triton $\mathrm{X}-100$ for $2 \mathrm{~h}$, and then in $\mathrm{PG} 21$ rabbit polyclonal antibody (1.75 $\mu \mathrm{g} / \mathrm{ml}$; EMD Millipore, Billerica, MA, USA) in $0.1 \mathrm{M}$ PBS with $0.2 \%$ Triton X-100 and $30 \%$ glycerol, for $48 \mathrm{~h}$ at $4{ }^{\circ} \mathrm{C}$. After incubation with primary antibody, slides were rinsed three times in PBS and then incubated in biotinylated donkey antirabbit secondary antibody (Jackson Laboratories, West Grove, PA, USA) at a dilution of 1:500 in 0.1 M PBS, for $90 \mathrm{~min}$. Slides were then incubated in Elite ABC peroxidase reagents (Vector Laboratories, Burlingame, CA, USA) for $60 \mathrm{~min}$ to visualize AR immunoreactive $(\mathrm{AR}+)$ myonuclei. We then stained tissues for 5 min with 4',6-diamidino2-phenylindole (DAPI; 1 $\mu \mathrm{g} / \mathrm{ml}$; Sigma, St Louis, MO, USA) to visualize all myonuclei. Finally, tissues were dehydrated in a series of ethanols, defatted in xylene, and coverslipped with DPX mounting medium.

To confirm the specificity of the antibodies used, we used two negative controls. First, the primary antibody was preadsorbed with $20 \times$ molar mass of the AR protein (custom peptide of the first 21 amino acids of the human AR protein, the peptide against which PG-21 was raised, Biosynthesis, Inc., Lewisville, TX, USA). In addition, we ran a no-primary control for each species, in which tissue sections were exposed to the same ICC protocol, but with the primary antibody omitted. Nuclei labeling was minimal in all sections exposed to these control protocols.

For each lizard, we determined the number of AR+ nuclei in the biceps in a $320 \mu \mathrm{m} \times 320 \mu \mathrm{m}$ area near the rostrocaudal center of the biceps, on each side of the animal. We then counted the total number of myonuclei in the same area, 
counting only nuclei within the muscle fibers. Following Holmes and Wade (2005) and Neal and Wade (2007), we then calculated the proportion of $\mathrm{AR}+$ nuclei from the total myonuclei for each individual.

Finally, we also measured the cross-sectional area of the biceps muscle fibers for each individual of all species (except A. bahorucoensis, for which alternate series of sectioned tissue were not available). We stained an alternate series of tissues with hematoxylin and eosin, and using ImageJ, measured the size of 20 arbitrarily selected fibers on each side of the animal, in the medial portion of the rostrocaudal center of the muscles. These measures were then averaged for each individual.

\section{Statistical analysis}

Because the data in this study were non-normally distributed, we transformed each behavioral variable by taking the logarithm of the raw value +1 , and we performed an arcsinesquare root transformation for the proportion of AR+ nuclei in the biceps. We used transformed data in all subsequent analyses.

To determine if the six species differed in rates of pushup display and locomotor movements, we used a series of analyses of variance (ANOVA), followed by Tukey's HSD post hoc tests. To determine the evolutionary relationships between AR expression, behavior, and morphology, we performed phylogenetic analyses using the squamate phylogeny in Pyron et al. (2013), pruned to include only the species in this study. We used phylogenetic generalized least squares (PGLS) regression analysis, using the caper package (Freckleton et al. 2002) in R ( $R$ Core Team 2014), to determine whether the proportion of AR+ nuclei in the biceps was associated with rates of pushups or locomotor movements. To determine whether rates of pushups and locomotion were correlated, and whether the proportion of $\mathrm{AR}+$ nuclei was correlated with muscle fiber size or body mass across species, we used generalized least squares correlation assuming
Brownian evolution of traits, using the $g l s$ function in the nlme package (Pinheiro et al. 2017) in R.

\section{Results}

The six species in this study differed dramatically in their use of the forelimbs during behavioral observations (Table 2). The rates of pushup displays ranged from those who rarely exhibit this behavior (A. bahorucoensis) to those that perform pushups more than eight times per min (A. carolinensis), with the other four species exhibiting intermediate pushup rates (ANOVA: $F_{5,410}=68.4, p<0.001$ ). Similarly, the rate of total locomotor movements range broadly $\left(F_{5,386}\right.$ $=58.1, p<0.001$ ), with the same two species exhibiting the most extreme behaviors; $A$. carolinensis moved $9 \times$ more frequently than A. bahorucoensis (Table 2). Among the other species, post hoc tests revealed that $A$. brevirostris and $A$. coelestinus moved at intermediate rates, and $A$. olssoni and A. cybotes moved relatively rarely (Table 2 ). We performed all analyses with both the rate of total locomotor movements, and the rates of the three types of movement (runs, crawls, and jumps) considered separately. Because the results were qualitatively similar in these analyses, we only present subsequent analyses with total movement rates below.

The average proportion of AR+ nuclei in the biceps ranged across the six species from 0.255 (A. cybotes) to 0.385 (A. carolinensis), although these means did not statistically differ (ANOVA: $F_{1,5}=1.41, p=0.246$ ). The effect size for this analysis is fairly low (partial $\eta^{2}=0.18$ ), suggesting that the small sample size included here may not be sufficient for detecting statistical significance. Further, there was substantial variation within several species, with the most extreme value belonging to an A. carolinensis individual whose proportion of $A R+$ nuclei was 0.16 , less than half the average value for the species (although this was not a statistical outlier and so was not removed from the analysis).

Table 2 Average (SE) of male body size, behavior, bicep fiber size, and the proportion of AR+ nuclei in bicep muscles of six Anolis lizard species

\begin{tabular}{|c|c|c|c|c|c|c|c|c|}
\hline Species & Mass (g) & Pushups (min) & $\begin{array}{l}\text { Total move- } \\
\text { ments (min) }\end{array}$ & Runs (min) & Crawls (min) & Jumps (min) & $\begin{array}{l}\text { Bicep fiber } \\
\text { size }\left(\mu \mathrm{m}^{2}\right)\end{array}$ & $\begin{array}{l}\text { Proportion } \\
\text { AR+ nuclei }\end{array}$ \\
\hline $\begin{array}{l}\text { A. bahoru- } \\
\text { coensis }\end{array}$ & $1.30(0.08)$ & $0.050^{\mathrm{a}}(0.033)$ & $0.209^{\mathrm{a}}(0.069)$ & $0.006^{\mathrm{a}}(0.002)$ & $0.126^{\mathrm{a}}(0.042)$ & $0.077^{\mathrm{a}}(0.022)$ & - & $0.305^{\mathrm{a}}(0.040)$ \\
\hline A. brevirostris & $2.60(0.15)$ & $0.859^{\mathrm{bc}}(0.103)$ & $0.669^{\mathrm{b}}(0.078)$ & $0.177^{\mathrm{bc}}(0.039)$ & $0.442^{\mathrm{b}}(0.062)$ & $0.050^{\mathrm{a}}(0.009)$ & 2912 (169) & $0.295^{\mathrm{a}}(0.031)$ \\
\hline A. carolinensis & $5.53(0.25)$ & $8.862^{\mathrm{d}}(0.697)$ & $1.820^{c}(0.119)$ & $0.444^{\mathrm{c}}(0.058)$ & $1.103^{\mathrm{c}}(0.058)$ & $0.273^{\mathrm{b}}(0.021)$ & 2166 (116) & $0.385^{\mathrm{a}}(0.052)$ \\
\hline A. coelestinus & $6.16(0.37)$ & $1.609^{\mathrm{bc}}(0.235)$ & $0.730^{\mathrm{b}}(0.069)$ & $0.093^{\mathrm{ab}}(0.016)$ & $0.520^{\mathrm{b}}(0.042)$ & $0.117^{\mathrm{a}}(0.022)$ & $3422(165)$ & $0.284^{\mathrm{a}}(0.022)$ \\
\hline A. cybotes & $7.95(0.42)$ & $2.201^{\mathrm{c}}(0.262)$ & $0.388^{a}(0.027)$ & $0.132^{\mathrm{ab}}(0.017)$ & $0.165^{\mathrm{a}}(0.015)$ & $0.091^{\mathrm{a}}(0.011)$ & $3896(342)$ & $0.255^{\mathrm{a}}(0.024)$ \\
\hline A. olssoni & $1.24(0.07)$ & $0.384^{\mathrm{ab}}(0.114)$ & $0.321^{\mathrm{a}}(0.073)$ & $0.051^{\mathrm{ab}}(0.022)$ & $0.145^{\mathrm{a}}(0.030)$ & $0.125^{\mathrm{a}}(0.025)$ & $1586(81)$ & $0.298^{\mathrm{a}}(0.059)$ \\
\hline
\end{tabular}

Superscripts indicate results of Tukey's HSD post hoc tests following ANOVA comparing across species; species with different superscripts for a trait were significantly different from one another 
Across the six species, the behavioral use of the forelimbs increased in association with the average proportion of AR+ nuclei in the biceps. The rate of locomotor movements was positively associated with AR expression in the biceps muscles (PGLS: Adj. $R^{2}=0.77, F_{1,4}=$ $17.29, p=0.014$, Fig. $2 \mathrm{a}$ ), and the rate of pushup displays was positively associated with biceps AR (PGLS: Adj. $R^{2}=0.59, F_{1,4}=8.29, p=0.045$, Fig. $2 b$ ). In addition, the rates of locomotion and pushup displays were highly correlated with one another across these six species (phylogenetic correlation: $p=0.018$ ).

The variation across species in AR+ nuclei was not associated with the mass of the animals (phylogenetic correlation: $p=0.89$ ) or the size of the fibers in the biceps (phylogenetic correlation: $p=0.075$ ). Pushup rate and locomotor rate were also not associated with bicep fiber size (phylogenetic correlation, pushups: $p=0.37$, locomotion: 0.24 ), or body size (phylogenetic correlation, pushups: $p=0.25$, locomotion, $p=0.59$ ).
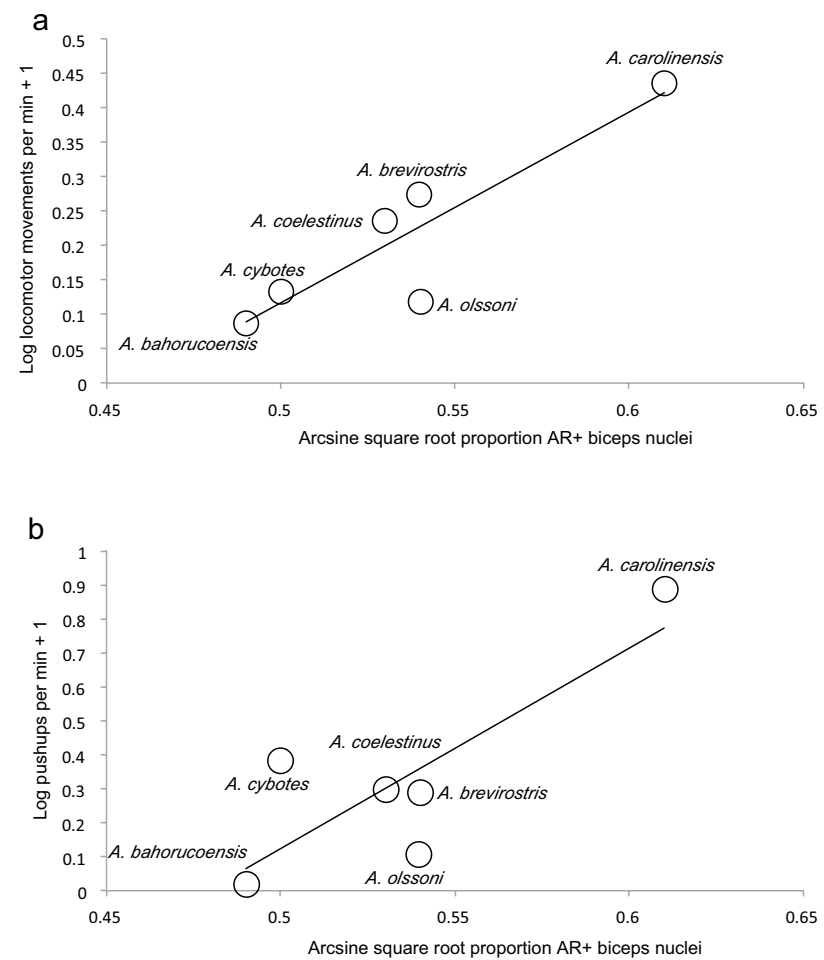

Fig. 2 Androgen receptor (AR) expression in biceps muscles and a rate of locomotor movements and $\mathbf{b}$ rate of social pushup displays in six Anolis species

\section{Discussion}

The results of this study support the hypothesis that the evolution of AR expression in skeletal muscles is associated with the evolution of the behavioral use of those muscles (Fuxjager et al. 2015; Mangiamele et al. 2016). Although this relationship appears to be strongly influenced by the green anole, A. carolinensis, which exhibits the highest rates of locomotor and display behaviors and has the highest average AR expression in the biceps (Fig. 2), the direction of the relationship is as we predicted. Together, these results suggest that the overall behavioral use of the biceps (and not just the muscle's use in a particular behavioral context) is associated with the concentration of receptors in its muscle fibers. For example, highly active lizards that aggressively defend a large territory from potential intruders would require muscles that could support both frequent movements around the territory and repeated displays to the intruders. Alternatively, increased AR expression in the biceps may have been selected to facilitate the use of the muscles in a specific context (such as in locomotion), and the receptors are then available to support the muscle's use in other contexts (such as social display). Further, there may be other uses of the forelimb driving the evolution of AR expression that were not considered in this study. For example, male frogs frequently use their forelimbs to grasp females during mating (Hannigan and Kelley 1986; Peters and Aulner 2000). While the use of forelimbs does not appear to play a critical role in anole mating behavior, we did not directly examine it here.

In our selection of species for this study, we aimed to include species that represented the full range of reported anole movement and display rates (Johnson et al. 2008; Johnson and Wade 2010). Although the observation time varied across the six species in this study, the patterns of behavior reported here are highly consistent with previous descriptions of the behavior of these species (e.g., Jenssen and Gladson 1984; Queral et al. 1995; Jenssen and Nunez 1998; Orell and Jenssen 1998). Our selection of species also resulted in a group in which locomotion and display rates were positively correlated, such that we cannot decouple the effects of AR expression on the two behaviors. Yet, locomotion and display rates are not necessarily coupled across all anole species. For example, species that primarily occur on small twigs in the canopy (i.e., species in the "twig" ecomorph) generally move frequently, actively foraging among the foliage, but display rarely (Hicks and Trivers 1983; Huyghe et al. 2007). On the other hand, species that primarily perch low on tree trunks with their heads oriented toward the ground (i.e., species in the "trunk-ground" ecomorph), are generally 
sit-and-wait predators that move rarely, but display frequently from their highly visible perches (Rand 1967; Losos 1990). This study included only one trunk-ground species (A. cybotes), and no twig species. Thus, future work could examine AR expression in a broader diversity of species to determine whether AR expression in the forelimb musculature is more closely associated with either locomotor behavior or display, or if the total use of the muscles, regardless of behavioral context, correlates with AR expression.

Increased AR expression may have many effects on skeletal muscle and the behaviors the muscle supports. Higher AR may allow greater utilization of circulating androgens, potentially altering the physiological capacity of the muscle. Using RNA-Seq, Fuxjager et al. (2016) found a wide variety of androgen-regulated genes that likely influence muscle movement in two passerine bird species. These genes and gene networks primarily included those that control lipid and carbohydrate metabolism and mitochondrial function, although androgens also influenced basic cellular functions such as ion and protein transport. Fuxjager et al. (2016) concluded that androgenic effects on skeletal muscles can increase fiber contractile strength and/or the energyproducing capacity that supports the endurance needed for muscular activity, although these effects may be species- or muscle-specific. In support of these transcriptional effects, experimental exposure to androgens also alters muscle fiber types in species- and muscle-specific patterns (e.g., Rubinstein et al. 1983; Eason et al. 2000; Holmes et al. 2007), demonstrating tissue-level changes in muscular metabolic capacity and strength.

Variation in AR expression can also interact with variation in circulating androgen levels to influence androgensensitive phenotypes. In anole lizards, as in many other vertebrates, the direct manipulation of testosterone alters a range of male phenotypes, including aggressive behaviors and social displays (e.g., Tokarz et al. 2002; Neal and Wade 2007; Cox et al. 2009). Husak and Lovern (2014) reported extensive variation in circulating testosterone among 18 Anolis species on four Caribbean islands. Surprisingly, they found a negative relationship between species aggression and testosterone in three of the four assemblages, including several species from the Dominican Republic examined here, although they found no relationship between testosterone and rates of social display across the group (Husak and Lovern 2014). Among the six species in the current study, measures of circulating testosterone are available for four: $A$. brevirostris, A. coelestinus, and A. cybotes (Husak and Lovern 2014) and A. carolinensis (Husak et al. 2007). Although there are only four species, there is a marginally significant relationship between these previously reported testosterone measures and the levels of AR expression in biceps reported here (Fig. 3; phylogenetic correlation: $p=0.051$ ).

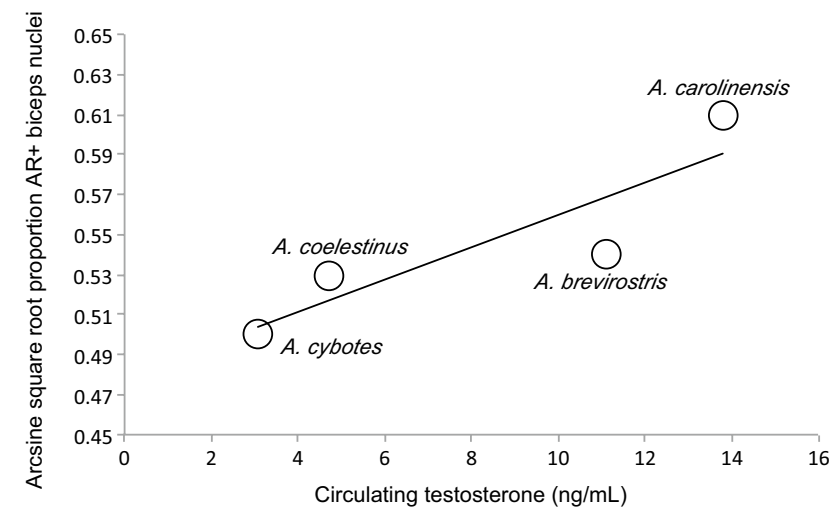

Fig. 3 Circulating testosterone and androgen receptor (AR) expression in bicep muscles of four Anolis lizard species

Similarly, Holmes and Wade (2005) found that within the green anole, A. carolinensis, testosterone increases the number of $\mathrm{AR}+$ myonuclei in a muscle involved in copulation (the retractor penis magnus, which controls movement of the hemipenes), but not in the muscle that controls movement of the dewlap, the throat fan used during social display (the ceratohyoid). Together, these results tentatively suggest that testosterone may differentially upregulate the expression of its receptors in the anole peripheral motor systems.

Finally, intraspecific variation in muscular AR and behavior has also been examined within the green anole. Neal and Wade (2007) measured AR expression in the ceratohyoid and the retractor penis magnus in unmanipulated adult males. In contrast to the interspecific relationship between biceps AR expression and behavioral use reported here, Neal and Wade (2007) found that variation in muscle AR was not associated with individual behavioral variation in male courtship or copulatory behaviors, and suggested that muscular tissues varied in androgen sensitivity by a mechanism other than variation in AR expression. This suggests that different endocrine mechanisms may regulate behavioral variation within a species than those driving the evolution of behavioral variation among closely related species. While intraspecific mechanisms may be conserved across evolutionary time, simply modified to give rise to behavioral diversity among species, interspecific changes in behavior could arise due to changes in pathways other than those used to create or maintain intraspecific behavioral variation.

In sum, we report an evolutionary correlation between behavioral phenotype and hormone receptor expression. Though causative studies on AR's influence on behavior have not yet been performed, correlative evidence for hormone receptor concentration causing behavioral variation is mounting, and there is no evidence that the behavioral use of a muscle mechanistically influences its hormone receptors. Indeed, Fuxjager et al. (2015) argued that, in manakins, behavioral differences among species could not account 
for variation in AR expression, because in species in which males (who use forelimb musculature in display) have high forelimb AR, females (who do not display) also have high AR. Instead, variation in receptor expression likely causes tissue-specific responses to globally circulating hormones that are often secreted by organs that are long distances from the tissues on which they act. This hypothesis has been supported in studies of the effects of hormone receptors on skeletal morphology. For example, Zheng and Cohn (2011) demonstrated that differences in AR and estrogen receptor densities between the fourth and second digits of developing mouse hands influence sexual dimorphism in digit length ratios, and Sanger et al. (2014) found that changes in the concentration of estrogen receptors determined sexually dimorphic face length in anole lizards. Together with our results, these data show the potential for selection to alter phenotypes that are regulated by hormones through the evolution of hormone receptors in the peripheral musculoskeletal systems.

Acknowledgements We thank our many colleagues and student collaborators for their assistance in the collection of lizard behavioral data over five field seasons; Kathleen Foster for advice on muscle morphology; and Brittney Ivanov, Jonathan King, Jimmy Roberts, and Mark Brodl for support in the laboratory. All procedures were performed with the approval of Trinity University's Animal Research Committee (protocols 042811-MJ1, 011415_MJ1, NSF_050213_MAJ3), the Ministerio de Medio Ambiente y Recursos Naturales, Dominican Republic, and Texas Parks \& Wildlife (permit SPR-0310-045). Funding for this work was provided by the National Science Foundation (IOS 1257021 to MAJ), an HHMI-funded undergraduate student fellowship (to DJC) from Trinity University, The Explorer's Club Youth Activity Fund (to DJC), and the Mind Science Foundation (to DJC).

\section{References}

Adkins-Regan E (2005) Hormones and animal social behavior. Princeton University Press, Princeton

Anzai W, Omura A, Diaz AC, Kawata M, Endo H (2014) Functional morphology and comparative anatomy of appendicular musculature in Cuban Anolis lizards with different locomotor habits. Zool Sci 31:454-463. https://doi.org/10.2108/zs130062

Brantley RK, Marchaterre MA, Bass AH (1993) Androgen effects on vocal muscle structure in a teleost fish with intersexual and intrasexual dimorphism. J Morphol 216:305-318

Bush JM, Quinn MM, Balreira EC, Johnson MA (2016) How do lizards determine dominance? Applying ranking algorithms to animal social behavior. Anim Behav 118:65-74. https://doi.org/10.1016/j. anbehav.2016.04.026

Chou PPH, Hsu HH, Chen SK, Yang SK, Kuo CM, Chou YL (2011) Effect of push-up speed on elbow joint loading. J Med Biol Eng 31:161-168. https://doi.org/10.5405/jmbe.772

Cox RM, Stenquist DS, Calsbeek R (2009) Testosterone, growth, and the evolution of sexual size dimorphism. J Evol Biol 22:15861598. https://doi.org/10.1111/j.1420-9101.2009.01772.x

Dill AK, Sanger TJ, Battles AC, Johnson MA (2013) Sexual dimorphisms in habitat-specific morphology and behavior in the green anole lizard. J Zool 290:135-142. https://doi.org/10.1111/ jzo. 12020
Eason JM, Schwartz GA, Pavlath GK, English AW (2000) Sexually dimorphic expression of myosin heavy chains in the adult mouse masseter. J Appl Physiol 89:251-258

Fisher M, Muth A (1989) A technique for permanently marking lizards. Herpetol Rev 20(2):45-46

Foster KL, Higham TE (2014) Context-dependent changes in motor control and kinematics during locomotion: modulation and decoupling. Proc R Soc B Biol Sci 281:20133331. https://doi. org/10.1098/rspb.2013.3331

Freckleton RP, Harvey PH, Pagel M (2002) Phylogenetic analysis and comparative data: a test and review of evidence. Am Nat 160:712-726. https://doi.org/10.1086/343873

Fuxjager MJ, Eaton J, Lindsay WR, Salwiczek LH, Rensel MA, Barske J, Sorenson L, Day LB, Schlinger BA (2015) Evolutionary patterns of adaptive acrobatics and physical performance predict expression profiles of androgen receptor-but not oestrogen receptor-in the forelimb musculature. Funct Ecol 29:11971208. https://doi.org/10.1111/1365-2435.12438

Fuxjager MJ, Lee JH, Chan TM, Bahn JH, Chew JG, Xiao X, Schlinger BA (2016) Research resource: hormones, genes, and athleticism: effect of androgens on the avian muscular transcriptome. Mol Endocrinol 30:254-271. https://doi.org/10.1210/ me.2015-1270

Haines RW (1939) A revision of the extensor muscles of the forearm in tetrapods. J Anat 73:211-233

Hale ME, Long JH Jr, McHenry MJ, Westneat MW (2002) Evolution of behavior and neural control of the fast-start escape response. Evolution 56:993-1007

Hannigan P, Kelley D (1986) Androgen-induced alterations in vocalizations of female Xenopus luevis: modifiability and constraints. J Comp Physiol A 158:517-527

Herbst KL, Bhasin S (2004) Testosterone action on skeletal muscle. Curr Opin Clin Nutr Metab Care 7:271-277

Herrel A, Vanhooydonck B, Porck J, Irschick DJ (2008) Anatomical basis of differences in locomotor behavior in Anolis lizards: a comparison between two ecomorphs. Bull Mus Comp Zool 159:213-238. https://doi.org/10.3099/0027-4100-159.4.213

Hertz PE, Huey RB, Stevenson RD (1993) Evaluating temperature regulation by field-active ectotherms - the fallacy of the inappropriate question. Am Nat 142:796-818. https://doi.org/10.1086/285573

Hicks RA, Trivers RL (1983) The social behavior of Anolis valencienni. In: Rhodin AGJ, Miyata K (eds) Advances in herpetology and evolutionary biology: essays in honor of ernest E. Williams. Museum of Comparative Zoology, Cambridge, pp 570-595

Holmes MM, Wade J (2005) Testosterone regulates androgen receptor immunoreactivity in the copulatory, but not courtship, neuromuscular system in adult male green anoles. J Neuroendocrinol 17(9):560-569. https://doi.org/10.1111/j.1365-2826.2005.01339.x

Holmes MM, Bartrem CL, Wade J (2007) Androgen dependent seasonal changes in muscle fiber type in the dewlap neuromuscular system of green anoles. Physiol Behav 91:601-608. https://doi. org/10.1016/j.physbeh.2007.03.022

Husak JF, Lovern MB (2014) Variation in steroid hormone levels among Caribbean Anolis lizards: endocrine system convergence? Horm Behav 65(4):408-415. https://doi.org/10.1016/j. yhbeh.2014.03.006

Husak JF, Irschick DJ, Meyers JJ, Lailvaux SP, Moore IT (2007) Hormones, sexual signals and performance of green anole lizards (Anolis carolinensis). Horm Behav 52:360-367. https://doi. org/10.1016/j.yhbeh.2007.05.014

Huyghe K, Herrel A, Vanhooydonck B, Meyers JJ, Irschick DJ (2007) Microhabitat use, diet, and performance data on the Hispaniolan twig anole, Anolis sheplani: pushing the boundaries of morphospace. Zoology 110(1):2-8

Irschick DJ, Losos JB (1998) A comparative analysis of the ecological significance of maximal locomotor performance in 
Caribbean Anolis lizards. Evolution 52:219-226. https://doi. org/10.2307/2410937

Jenssen TA (1977) Evolution of anoline lizard display behavior. Am Zool 17(1):203-215. https://doi.org/10.1093/icb/17.1.203

Jenssen TA, Gladson NL (1984) A comparative display analysis of the Anolis brevirostris complex in Haiti. J Herpetol 18:217-230

Jenssen TA, Nunez SC (1998) Spatial and breeding relationships of the lizard, Anolis carolinensis: evidence of intrasexual selection. Behaviour 135:981-1003

Jenssen TA, Orrell KS, Lovern MB (2000) Sexual dimorphisms in aggressive signal structure and use by a polygynous lizard, Anolis carolinensis. Copeia 2000(1):140-149. https://doi. org/10.1643/0045-8511(2000)2000[0140:SDIASS]2.0.CO;2

Johnson MA, Wade J (2010) Behavioural display systems across nine Anolis lizard species: sexual dimorphisms in structure and function. Proc R Soc B 277(1688):1711-1719. https://doi.org/10.1098/ rspb.2009.2323

Johnson MA, Leal M, Schettino LR, Lara AC, Revell LJ, Losos JB (2008) A phylogenetic perspective on foraging mode evolution and habitat use in West Indian Anolis lizards. Anim Behav 75:555-563. https://doi.org/10.1016/j.anbehav.2007.06.012

Johnson MA, Revell LJ, Losos JB (2010) Behavioral convergence and adaptive radiation: effects of habitat use on territorial behavior in Anolis lizards. Evolution 64:1151-1159. https://doi. org/10.1111/j.1558-5646.2009.00881.x

Johnson MA, Lopez MV, Whittle TK, Kircher BK, Dill AK, Varghese D, Wade J (2014) The evolution of copulation frequency and the mechanisms of reproduction in male Anolis lizards. Curr Zool 60:768-777. https://doi.org/10.1093/czoolo/60.6.768

Kamath A, Losos JB (2017) The erratic and contingent progression of research in territoriality: a case study. Behav Ecol Sociobiol 71:89. https://doi.org/10.1007/s00265-017-2319-z

Leal M, Rodriguez Robles JA (1997) Signaling displays during predator-prey interactions in a Puerto Rican anole, Anolis cristatellus. Anim Behav 54:1147-1154. https://doi.org/10.1006/ anbe.1997.0572

Losos JB (1990) Concordant evolution of locomotor behavior, display rate, and morphology in West Indian Anolis lizards. Anim Behav 39:879-890. https://doi.org/10.1016/S0003-3472(05)80952-2

Losos JB (2009) Lizards in an evolutionary tree. University of California Press, Berkeley

Mangiamele LA, Fuxjager MJ, Schuppe ER, Taylor RS, Hödl W, Preininger D (2016) Increased androgenic sensitivity in the hind limb musculature system marks the evolution of a derived gestural display. Proc Natl Acad Sci USA 113:5664-5669. https:// doi.org/10.1073/pnas.1603329113

Neal JK, Wade J (2007) Androgen receptor expression and morphology of forebrain and neuromuscular systems in male green anoles displaying individual differences in sexual behavior. Horm Behav 52(2):228-236. https://doi.org/10.1016/j.yhbeh.2007.04.009

Nicholson KE, Harmon LJ, Losos JB (2007) Evolution of Anolis lizard dewlap diversity. PLoS One 2:e274. https://doi.org/10.1371/ journal.pone.0000274

Ord TJ, Martins EP (2006) Tracing the origins of signal diversity in anole lizards: phylogenetic approaches to inferring the evolution of complex behaviour. Anim Behav 71:1411-1429. https://doi. org/10.1016/j.anbehav.2005.12.003

Orell KS, Jenssen TA (1998) Display behavior of the lizard Anolis bahorucoensis: an anole with a diminutive dewlap. Carib J Sci 34:113-125
Peters SE, Aulner DA (2000) Sexual dimorphism in forelimb muscles of the bullfrog, Rana catesbeiana: a functional analysis of isometric contractile properties. J Exp Biol 203:3639-3654

Pinheiro J, Bates D, DebRoy S, Sarkar D, R Core Team (2017) nlme: linear and nonlinear mixed effects models. R package version 3.1-131. R Foundation for Statistical Computing

Prum RO (1990) Phylogenetic analysis of the evolution of display behavior in the neotropical manakins (Aves: Pipridae). Ethol 84:202-231

Pyron RA, Burbrink FT, Wiens JJ (2013) A phylogeny and revised classification of Squamata, including 4161 species of lizards and snakes. BMC Evol Biol 13:93. https://doi. org/10.1186/1471-2148-13-93

Queral A, Garcia R, Powell R, Parmerlee JS, Smith DD, Lathrop A (1995) Agonistic responses by a grass anole, Anolis olssoni from the Dominican Republic, to male conspecifics. Amphib Reptil 16:313-321. https://doi.org/10.1163/156853895X00398

R Core Team (2014). R: a language and environment for statistical computing. R Foundation for Statistical Computing, Vienna

Rand AS (1967) Ecology and social organization in the iguanid lizard Anolis lineatopus. Proc US Natl Mus 122:1-79. https://doi. org/10.5479/si.00963801.122-3595.1

Rand MN, Breedlove SM (1992) Androgen locally regulates rat bulbocavernosus and levator ani size. J Neurbiol 23:17-30

Regnier M, Herrera AA (1993) Changes in the contractile properties by androgen hormones in sexually dimorphic muscles of male frogs (Xenopus laevis). J Physiol 461:565-581

Rubinstein NA, Erulkar SD, Schneider GT (1983) Sexual dimorphism in the fibers of a 'clasp' muscle of Xenopus laevis. Exp Neurol $82: 424-431$

Sanger TJ, Seav SM, Tokita M, Langerhans RB, Ross LM, Losos JB, Abzhanov A (2014) The oestrogen pathway underlies the evolution of exaggerated male cranial shapes in Anolis lizards. Proc R Soc B 281:20140329. https://doi.org/10.1098/rspb.2014.0329

Stamps JA (1977) Social behavior and spacing patterns in lizards. In: Gans C, Tinkle DW (eds) Biology of the reptilia, vol 7. Academic Press, London, pp 265-334

Stamps J (1994) Territorial behavior: testing the assumptions. Adv Study Behav 23:173-232

Suzuki D, Murakami G, Minoura N (2002) Histology of the bone-tendon interfaces of limb muscles in lizards. Ann Anat 184:363-377. https://doi.org/10.1016/S0940-9602(02)80057-7

Tokarz RR, McMann S, Smith LC, John-Alder H (2002) Effects of testosterone and season on the frequency of dewlap extensions during male-male interactions in the lizard Anolis sagrei. Horm Behav 41:70-79. https://doi.org/10.1006/hbeh.2001.1739

Veney SL, Wade J (2004) Steroid receptors in the adult zebra finch syrinx: a sex difference in androgen receptor mRNA, minimal expression of estrogen receptor alpha and aromatase. Gen Comp Endocrinol 136:192-199. https://doi.org/10.1016/j.ygcen.2003.12.017

Wade J (2012) Sculpting reproductive circuits: relationships among hormones, morphology and behavior in anole lizards. Gen Comp Endocrinol 176:456-460. https://doi.org/10.1016/j. ygcen.2011.12.011

Zheng Z, Cohn MJ (2011) Developmental basis of sexually dimorphic digit ratios. Proc Natl Acad Sci USA 108:16289-16294. https:// doi.org/10.1073/pnas.1108312108 